\title{
Pengembangan Lembar Kerja Peserta Didik (LKPD) pada Materi Radiasi Benda Hitam dengan Berbantuan PhET Simulations
}

Nur Isro'atul Fauziyah*, Imam Sucahyo

Pendidikan Fisika, Universitas Negeri Surabaya

*Email: nur.fauziyah.99@gmail.com

DOI: https://doi.org/10.33369/pendipa.5.3.384-388

\begin{abstract}
[Development of Student Worksheets (LKPD) on Black Bosy Radiation Material with PhET simulations] The aim of this study was to determine the validity, practicality, and effectiveness of student worksheets on Black Body Radiation with PhET simulations. The method of this research is Research and Development with ADDIE model (Analysis, Design, Development, Implementation, Evaluations). The subjects in this research were 15 students of class XII MIA 5 in MAN 1 Lamongan 2020/2021 school year in the even semester. The result of the validations of the learning tools student worksheets from the experts have met the standard, namely the percentage of content eligibility is $89.30 \%$, the percentage of language is $93.30 \%$, the percentage of presentation is $92 \%$, and the graphic percentage is $95 \%$. The result of the percentage each point from the three validators show that student worksheets that have been made are included in the very valid category. This is supported by the result of students responses through questionnaires distributed about student worksheets in which the percentage is $84.44 \%$ which is included in the very good category. The result of the evaluation of students after learning using student worksheets showed that $87 \%$ of students completed and $13 \%$ of students did not completed. So, it can be concluded that the student worksheets that were made were valid with excellent and effective student responses to improve students understanding of Black Body Radiation material.
\end{abstract}

Keywords: Student Worksheets, Black Body Radiation, PhET simulations.

\begin{abstract}
ABSTRAK
Tujuan dari penelitian ini adalah untuk mengetahui kevalidan, kepraktisan, dan keefektifan Lembar Kerja Peserta Didik (LKPD) pada materi Radiasi Benda Hitam dengan berbantuan PhET simulations. Metode penelitiannya aadala Penelitian dan Pengembangan dengan model ADDIE (Analysis, Design, Development, Implementation, Evaluation). Subjek penelitian yaitu 15 peserta didik pada kelas XII MIA 5 di MAN 1 Lamongan tahun pelajaran 2020/2021 pada semester Genap. Hasil validasi perangkat pembelajaran Lembar Kerja Peserta Didik (LKPD) dari para ahli telah memenuhi standart dimana persentase kelayakan isis sebesar $89.30 \%$, persentase kebahasaan sebesar $93.30 \%$, persentase sajian sebesar 92\%, dan persentase kegrafisan sebesar 95\%. Hasil persentase tiap poin dari tiga validator menunjuakkan bahwa Lembar Kerja Peserta Didik (LKPD) yang telah dibuat termasuk kategori sangat valid. Hal tersebut disukung oleh hasil respon dari peserta didik malalui angket yang dibagikan mengenai Lembar Kerja Peserta Didik (LKPD) dimana persentasenya sebesar 84.44\% termasuk dalam kategori sangat baik. Hasil evaluasi peserta didik setelah melakukan pembelajaran menggunakan Lembar Kerja Peserta Didik (LKPD) menunjukkan bahwa $87 \%$ peserta didik tuntas dalam pembelajaran dan $13 \%$ tidak tuntas dalam pembalajaran. Sehingga dapat disimpulkan bahwan Lembar Kerja Peserta Didik (LKPD) yang telah dibuat valid dengan respon peserta didik yang sangat baik dan efektif untuk meningkatkan pemahaman peserta didik mengenai materi Radiasi Benda Hitam.
\end{abstract}

Kata kunci: LKPD, Radiasi Benda Hitam, PhET simulations. 


\section{PENDAHULUAN}

Pendidikan sangat berperan penting dalam kemajuan suatu bangsa, termasuk di Indonesia (Saputro, 2019). Pendidikan berperan mewujudkan suatu bangsa agar lebih sejahtera, Makmur, dan dapat bersaing dengan negara lainnya. Oleh sebab itu pemerintah Indonesia selalu memperbaiki sistem pendidikan guna menaikkan kualitas pendidikan di Indonesia (Sari, 2019).

Pada abad 21 ini perkembangan teknologi sangat pesat yang bertujuan untuk mempermudah aktivitas manusia (Yolfany, 2017). Seiring berkembangnya teknologi, dunia Pendidikan juga ikut berkembang contohnya seperti banyak aplikasi yang dapat membantu pemahaman peserta didik mengenai suatu materi dan banyak video-video pembelajaran.

Fisika adalah cabang dari ilmu alam. Fisika merupakan pengetahuan hasil dari kgiatan manusia, gagasan, dan konsep tentang alam yang diperoleh dari pengalaman melalui proses ilmiah (Prihatiningtyass, dkk. 2013).

Salah satu materi fisika yang membutuhkan pemahaman konsep dalah Radiasi Benda Hitam. Pada materi radiasi benda hitam terdapat konsep Pergeseran Wien, pada konsep ini sulit dilakukan praktikum secara nyata di ranah SMA dikarenakan keterbatasan alat praktikum sehingga perlu menggunakan Lab Virtual, tetapi yang mudah diaplikasikan kepada peserta didik adalah PhET simulations (Yusuf, 2013). PhET simulations merupakan media pembelajaran dalam bentuk laboratorium virtual untuk membangun pengetahuan peserta didik. Melalui PhET simulations penjelasan suatu materi akan terlihat secara nyata sehingga akan lebih mudah difahami (Yulia, dkk. 2018). Berdasarkan penelitian yang dilakukan oleh Tirtawaty dan Nova (2018) menyatakan bahwa PhET simulations efektif digunakan dalam proses pembelajaran, dimana persentase rata-rata aktivitas siswa setelah kegiatan pembelajaran mencapai $87.50 \%$ dan hasil dari evaluasi siswa diperoleh skor rata-rata $78.50 \%$.

Bedasarkan hasil penelitian yang dilakukan Perdana, dkk (2017) di SMAN 15 Bekasi dengan membagikan angket kepada 69 siswa, 56\% siswa merasa kesulitan memahami materi fisika, $28.90 \%$ alasan banyak symbol, rumus, dan banyak istilah yang digunakan, $42 \%$ dengan alasan praktikumnya kurang karena ketersediaan alat praktikum yang terbatas (Perdana, dkk. 2017).

Pembelajaran fisika memerlukan bahan ajar, salah satunya adalah lembar kerja peserta didik (LKPD). Lembar kerja peserta didik (LKPD) berisi soal atau kegiatan yang akan dilakukan peserta didik dalam proses pembelajaran (Nurdin, 2016).

Berdasarkan uraian tersebut peneliti mengembangkan sebuah Lembar Kerja Peserta Didik (LKPD) pada materi Radiasi Benda Hitam dengan berbantuan PhET simulations yang bertujuan untuk mengetahui kevalidan, kepraktisan, dan keefektifn Lembar Kerja Peserta Didik (LKPD). PhET simulations digunakan untuk menggantikan alat-alat praktikum laboratorium Radiasi Benda Hitam yang belum tersedia di MAN 1 Lamongan.

\section{METODE PENELITIAN}

Penelitian dilaksanakan di MAN 1 Lamongan di kelas XII MIA (Matematika dan Ilmu Alam) 5 sebanyak 15 peserta didik. Peneliti melakukan penelitian pada tahun ajaran 2020/2021 pada semester genap. Penelitian ini menggunakan metode Penelitian dan Pengembangan dengan model ADDIE (Analysis, Design, Development, Implementation, Evaluation).

Desain penelitian sebagai berikut:

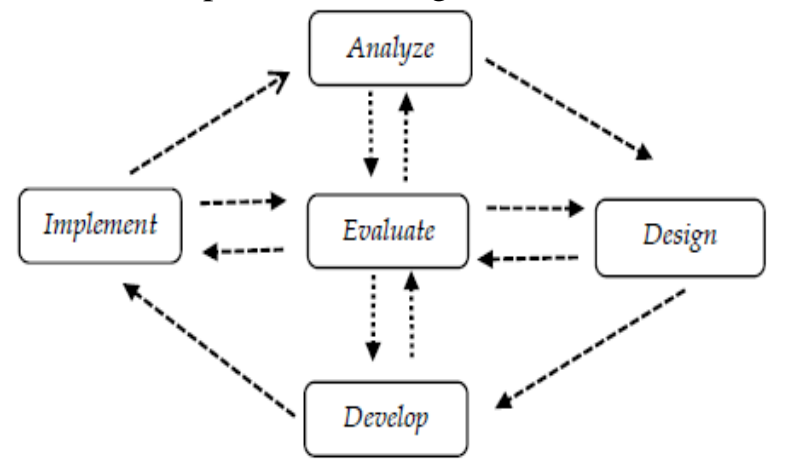

Gambar 1. Tahapan model ADDIE (sumber: Anglada, 2007)

Peneliti menggunakan One-shot Case Study sebagai hasil belajar. Peneliti akan memberikan post-test di akhir pembelajaran.

$$
\text { L ----> U }
$$

Gambar 2. Skema metode penelitian 
(sumber: Prabowo, 2011)

Pengumpulan dan analisi data pada penelitian ini sebagai berikut:

a. Validasi

Pada penelitian, lembar validasi diisi oleh validator untuk mengetahui kevalidan perangkat pembelajjaran Lembar Kerja

Peserta Didik (LKPD).

Analisis data validasi menggunakan skala Likert.

\begin{tabular}{|l|c|}
\hline \multicolumn{1}{|c|}{ Penilaian } & Skor \\
\hline Sangat Valid & 5 \\
\hline Valid & 4 \\
\hline Cukup & 3 \\
\hline Kurang valid & 2 \\
\hline Kurang valid sekali & 1 \\
\hline
\end{tabular}

Tabel 1 Skor penilaian validasi

(sumber: Risuwan 2021)

Persentase skor menggunakan rumus:

$$
\%=\frac{\text { nilai pengumpulan data }}{\text { nilai maksimum }} \times 100 \%
$$

\begin{tabular}{|l|l|}
\hline \multicolumn{1}{|c|}{ Persentase } & \multicolumn{1}{c|}{ Kriteria } \\
\hline $1 \%-20 \%$ & Kurang valid sekali \\
\hline $21 \%-40 \%$ & Kurang valid \\
\hline $41 \%-60 \%$ & Cukup \\
\hline $61 \%-80 \%$ & Valid \\
\hline $81 \%-100 \%$ & Sangat valid \\
\hline
\end{tabular}

Tabel 2 Persentase Kevalidan

b. Angket

Angket digunakan untuk menilai kepraktisan lembar kerja peserta didik (LKPD) ditinjau dari hasil rata-rata respon peserta didik. Analisis lembar angket respon peserta didik mengenai LKPD menggunakan skala Likert.

\begin{tabular}{|l|c|}
\hline \multicolumn{1}{|c|}{ Penilaian } & Skor \\
\hline Sangat baik & 5 \\
\hline Baik & 4 \\
\hline Cukup & 3 \\
\hline Kurang baik & 2 \\
\hline Kurang sekali & 1 \\
\hline
\end{tabular}

Table 3 Skor penilaian angket (sumber: Riduwan, 2012)

Untuk nilai persentase angket menggunakan rumus:

$$
\%=\frac{\text { nilai yang didapat }}{\text { nilai maksimal }} \times 100 \%
$$

\begin{tabular}{|c|c|}
\hline Persentase & Kriteria \\
\hline $1 \%-20 \%$ & Kurang sekali \\
\hline
\end{tabular}

\begin{tabular}{|l|l|}
\hline $21 \%-40 \%$ & Kurang \\
\hline $41 \%-60 \%$ & Cukup \\
\hline $61 \%-80 \%$ & Baik \\
\hline $81 \%-100 \%$ & Sangat baik \\
\hline
\end{tabular}

Table 4 Persentase angket

c. Penilaian tes

Tes digunakan untuk menguji pemahaman peserta didik. Post-test dilakukan setelah pembelajaran.

Nilai hasil dari evaluasi peserta didik disajika dalam bentuk angka yang memiliki rentan 0100 (Permendikbud No. 23 Tahun 2016). Melalui penghitungan persentase ketuntasan secara klasikal sebagai berikut:

$$
\text { ketuntasan }=\frac{\text { jumlah siswa tuntas }}{\text { jumlah satu kelas }} \times 100 \%
$$

Kelas dikatakan tuntas apabila ketuntasan klasikal $\geq 80 \%$ dan dapat diintepretasikan produk pengembangan dalam kategori baik / efektif.

\section{HASIL DAN PEMBAHASAN}

Hasil dari penelitian yang telah dilakukan sebagai berikut:

1. Validasi

Validasi perangkat pembelajaran dilakukan oleh 3 dosen ahli dalam bidangnya di jurusan Fisika Universitas Negeri Surabaya. Hasil validasi perangkat pembelajaran dapat ditunjukkan pada grafik berikut:

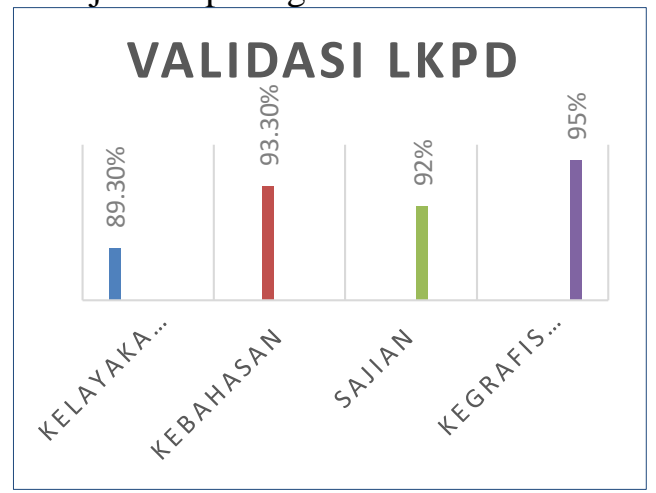

\section{Grafik 1 Hasil validasi LKPD}

Berdasarkan dari grafik diatas kelayakan isi memperoleh persentase sebesar $89.30 \%$ termasuk kategori sangat valid. Hasil validasi kebahasaan diperoleh $93.30 \%$ dengan kategori sangat valid. Hasil validasi sajian diperoleh $92 \%$ termasuk kategori sangat 
valid. Hasil validasi kegrafisan diperoleh 95\% termasuk kategori sangat valid.

2. Kepraktisan

Kepraktisan perangkat pembelajaran dapat dilihat dari angket respon kepada 15 peserta didik yang dibagikan.

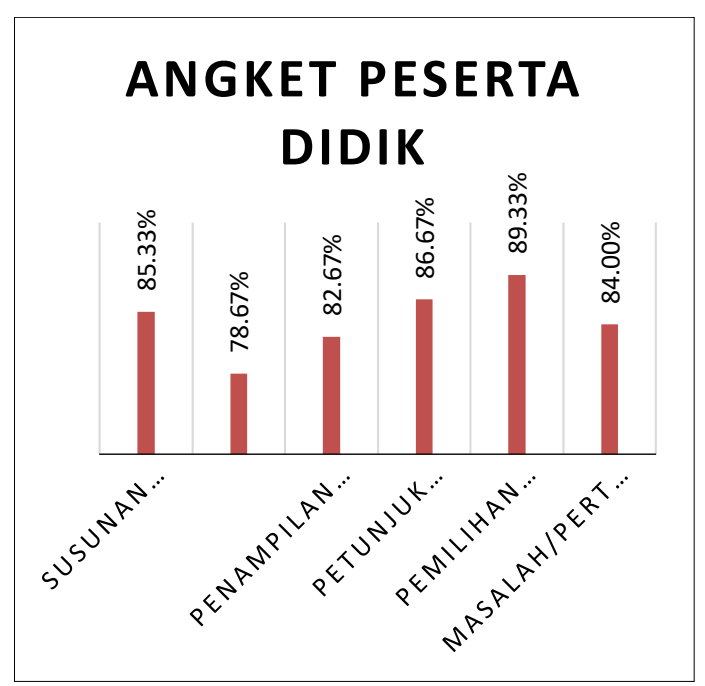

Grafik 2 Persentase hasil angket peserta didik

Point-poin yang ada dalam angket adalah (1) Runtut dan sistematis sehingga mudah difahami, (2) Bahasa yang digunakan mudah difahami dan tidak bermakna ganda, (3) Penampilan LKPD (penyajian, ilustrasi gambar, dan pengaturan tata letak) membuat tertarik, (4) Petunjuk kegiatan dalam LKPD jelas sehingga mempermudah dalam melakukan semua kegiatan, (5) Pemilihan jenis huruf, font, dan spasi yang digunakan mempermudah dalam pembacaan LKPD, dan (6) Masalah/pertanyaan yang disajikan dapat dimengerti dengan baik.

Pada poin 1 memperoleh persentase sebesar $85.33 \%$ yang termasuk dalam kategori sangat baik. Poin 2 memperoleh $78.67 \%$ termasuk dalam kategori baik. Poin 3 memperoleh $82.67 \%$ termasuk kategori sangat baik. Poin 4 memperoleh $86.67 \%$ termasuk kategori sangat baik. Poin 5 memperoleh $89.33 \%$ termasuk kategori sangat baik. Poin 6 memperoleh persentase sebanyak $84 \%$ termasuk dalam kategori sangat baik.

\section{Keefektifan}

Keefektifan perangkat pembelajaran dilihat dari hasil post-test yang dilakukan setelah pembelajaran sebagai berikut:

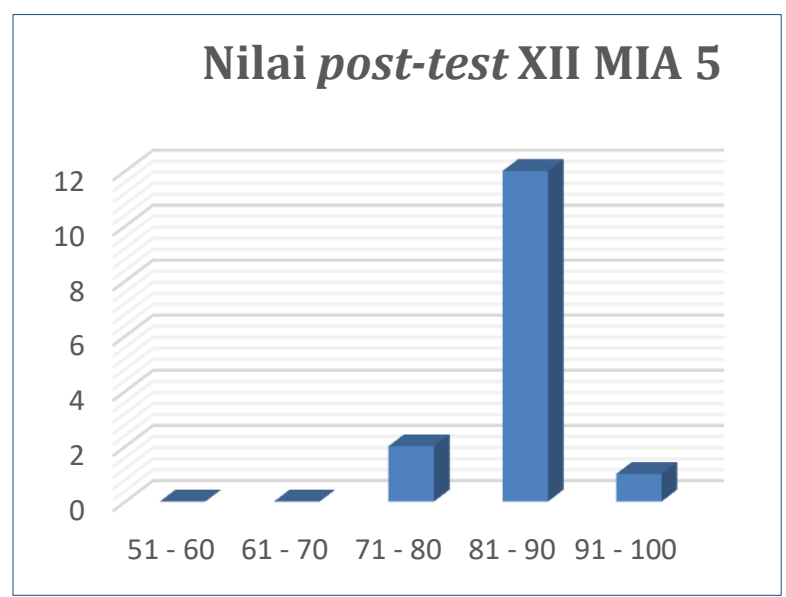

Grafik 3 Hasil nilai post-test XII Mia 5

Berdasarkan dari hasil wawancara yang telah dilakukan dengan guru fisika MAN 1 Lamongan, dapat diketahui nilaiKriteria Kelulusan Minimum (KKM) sebesar 80. Berdasarkan grafik diatas diketahui bahwa pada rentang nilai $71-80$ terdapat 2 peserta didik, pada nilai 81 - 90 terdapat 12 peserta didik, dan pada rentang nilai $91-100$ terdapat 1 peserta didik. Berdasarkan nilai KKM terdapat 13 peserta didik yang tuntas dalam pembelajaran dan 2 peserta didik yang tidak tuntas dalam pembelajaran.

Dari hasil post-test tersebut apabila dipersentasekan hasilnya sebagai berikut:

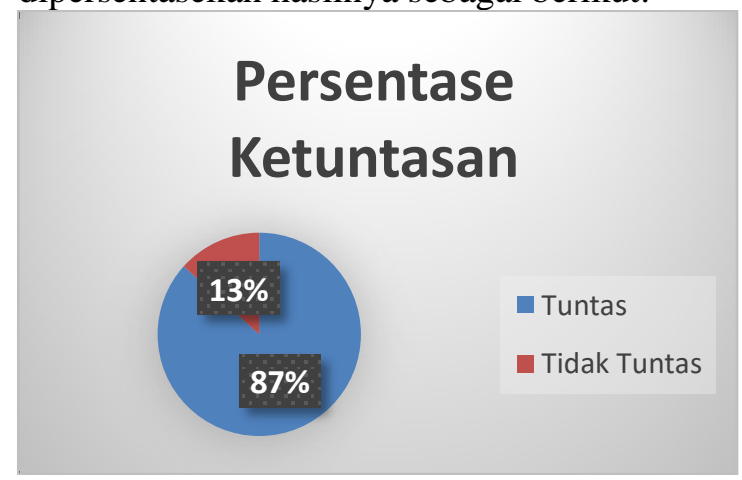

Grafik 4 Persentasi ketuntasan

Dari grafik persentase ketuntasan di atas dapat dilihat bahwa $87 \%$ peserta didik yang tuntas dan $13 \%$ peserta didik yang tidak tuntas dalam pembelajaran. 


\section{KESIMPULAN}

Dapat disimpulkan dari penelitian ini bahwa perangkat pembelajaran Lembar Kerja Peserta Didik (LKPD) pada materi Radiasi Benda Hitam dengan berbantuan PhET simulations yang telah dibuat sangat valid dengan persentase $92.40 \%$ dengan persentase kepraktisan sebesar $84.44 \%$ yang termasuk dalam kategori sangat baik dan efektif digunakan untuk peserta didik dengan persentase ketuntasan sebesar $87 \%$ dari 15 peserta didik yang telah melakukan pembelajaran.

\section{DAFTAR PUSTAKA}

Abdjul Tirtawaty, N. N. (2018). Developing Devide of Learning Based on Virtual Laboratory Through Phet Simulation for Physics Lesson with Sound Material. International Journal of Science: Basic and Applied Research (IJSBAR), 39, 105-115.

Anglada, D. (2007, 7 12). An Introduction to Instructional Design: Utilizing a Basic Design Model. Retrieved Februari 20, 2019, from http://www.pace.edu/ctlt/newsletter.

Nurdin S, A. (2016). Kurikulum Pembelajaran. Jakarta: Rajawali Pers.

Perdana Akbar, S. S. (2017). Pengembangan Lembar Kerja Siswa Berbasis Discovery Learning Berbantuan Phet Interactive Simulations pada Materi Hukum Newton. Jurnal Wahana Pendidikan Fisika, 2, 73-79.

Prabowo. (2011). Metodologi Penelitian (Sains dan Pendidikan Sains). Surabaya: Unesa University Pers.

Prihatiningtyass S, P. T. (2013). Implementasi Simulasi Phet dan Kit Sederhana untuk Mengerjakan Keterampilan Psikomotor Siswa pada Pokok Bahasan Alat Optik. Jurnal Pendidikan IPA Indonesia, 18-22.

Riduwan. (2012). Dasar-dasar Satistika. Bandung: Alfabeta.
Saputro Vichi CE, P. S. (2019). Pengembangan Alat Peraga Mesin Carnot sebagai Media Pembelajaran dengan Model Pembelajaran Inkuiri Terbimbing. IPF, 08, 716-721.

Sari Novita A, P. S. (2019). Pengembangan Alat Percobaan Tumbukan sebagai Penunjang Pembelajaran Fisika Materi Momentum untuk Melatihkan Keterampilan Proses Sains. IPF, 08, 722-726.

Yolfany, M. (2017). Pemanfaatan Informasi dalam Website E-Commerce. Surabaya: Universitas Airlangga.

Yulia Irma, C. E. (2018). Pengembangan LKPD Berbasis Inquiry Berbantuan Simulasi Phet untuk Meningkatkan Penguasaan Konsep Gelombang Cahaya di Kelas XI MIPA SMAN 2 Kota Bengkulu. Jurnal Kumparan Fisika, Volume 1 Nomor 3.

Yusuf, S. (2013). Pengembangan Perangkat Pembelajaran Fisika Berbasis Media Laboratorium Virtual pada Materi Dualisme Gelombang Partikel di SMA Tut Wiru Handayani Makasar. Jurnal Pendidikan IPA Indonesia, 189-194. 